\title{
The Relationship of the Family Role as a Medication Supervisor with Medication Adherence in Children with Pulmonary Tuberculosis in Jember City Area
}

\author{
Qulud Arum Pratiwi ${ }^{1}$, Lantin Sulistyorini2 ${ }^{*}$, Dini Kurniawati ${ }^{3}$
}

\author{
${ }^{1}$ Nursing Science Study Program, Faculty of Nursing, University of Jember; Indonesia \\ 2Pediatric Nursing, Faculty of Nursing, University of Jember, Indonesia; lantin_s.psik@unej.ac.id (Corresponding Author) \\ 3Maternity Nursing, Faculty of Nursing, University of Jember , Indonesia
}

\begin{tabular}{l} 
Article Info: \\
\hline Submitted: \\
02-08-2021 \\
Revised: \\
06-09-2021 \\
Accepted: \\
24-09-2021
\end{tabular}

DOI:

https://doi.org/10.53713/nhs.v1i2.37

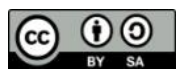

This work is licensed

under CC BY-SA License.

\begin{abstract}
Medication adherence in children requires the role of the family. The family is the closest person who is trusted and willing to help the treatment process voluntarily so that there is no risk of dropping out of drugs or the occurrence of death due to pulmonary tuberculosis. The purpose of this study was to determine the relationship between the family role and medication adherence in children with pulmonary tuberculosis in Jember city area. This study used a cross sectional research design and was conducted on 32 families who act as medication supervisors in children with pulmonary tuberculosis and conducted by total sampling. The measuring instrument used a questionnaire on the family role as a medication supervisor and a medication adherence questionnaire in children with pulmonary tuberculosis. The results showed that the family role in the good category was 25 children and medication adherence was low as many as 19 children. The results of Spearman's test statistic showed that there was a relationship between the role of the family as a medication supervisor with medication adherence in children with pulmonary tuberculosis with a $p$ value $<0.05$, namely $0.12<0.05$. The strength of the moderate relationship with an $r$ value of 0.438 indicates a unidirectional relationship. The conclusion of this study was that there is a relationship between the family role as a medication supervisor with medication adherence in children with pulmonary tuberculosis in Jember city area.
\end{abstract}

Keywords: family role; medication adherence; pulmonary tuberculosis in children

\section{INTRODUCTION}

Pulmonary tuberculosis in children is a contagious infection caused by Mycobacterium tuberculosis that attacks the lungs of children. Childhood tuberculosis is a contagious infectious disease that occurs in children aged 0-14 years. The presence of childhood tuberculosis can explain the effectiveness of tuberculosis control programs such as detection of adult tuberculosis cases, contact tracing, and BCG vaccination which is an immunization that must be given to infants to prevent tuberculosis (Kementerian Kesehatan Republik Indonesia, 2013). The high dropout rate, inadequate treatment and resistance to Anti Tuberculosis Drugs cause failure in treatment. Tuberculosis treatment takes a long time (up to 6-8 months) to achieve cure and with a combination (combination) of several kinds of drugs, so it is not uncommon for patients to stop taking medication before the treatment period is finished which results in failure in tuberculosis treatment (World Health Organization, 2013). Efforts to achieve cure from tuberculosis, all patients require regularity or adherence to taking medication. Compliance with taking medication in children with tuberculosis is the attitude or behavior of children in taking medication according to the type, dose, method of drinking, drinking time and the number of days determined to spend the drug in accordance with the recommendations from health services based on the national tuberculosis control guidelines. If a tuberculosis patient can regularly take his medicine for 2 weeks, this tuberculosis bacteria will be broken down and not at risk for infection. This means that if the patient has high medication adherence, the cure rate will increase, so that the risk of drug-resistant tuberculosis cases can be prevented (Widiyanto, 2016).

According to WHO estimates, it is estimated that 1,000,000 children aged 0-14 years-experience tuberculosis every year or as much as $10 \%$ of all tuberculosis cases. In 2017 as many as 233,000 died from tuberculosis (World Health Organization, 2018). In Indonesia in 2018 the number of tuberculosis cases in children aged 0-14 was 10.62\%. In East Java Province alone, there were 1823 cases of child tuberculosis in the female sex and 1832 male cases (Kementerian Kesehatan Republik Indonesia, 2019). Jember Regency in 2017 was included in the high incidence of 
tuberculosis, which was the second highest after Surabaya (Departemen Kesehatan Republik Indonesia, 2018). The results of a preliminary study at the Jember District Health Office of child tuberculosis cases that occurred per health facility in the last three years, namely in 2017 as many as 212 cases, in 2018 as many as 206 cases and in 2019 as many as 180 cases.

The management of tuberculosis has been comprehensively structured which includes patient findings, and followed up with treatment known as the DOTS system (Directly Observed Treatment Shortcourse). One of the strategies of this DOTS is the need for direct supervision from the drug taking supervisor when swallowing drugs in patients. Supervisors for taking this medicine can come from health workers or close family members (Departemen Kesehatan Republik Indonesia, 2006). Families can be used as drug-taking supervisors because they are known, trusted and approved by health workers and patients, besides that they must be respected, respected and live close to patients and are willing to help sufferers voluntarily. Before becoming a drug-taking supervisor, the family has been given education by the health officer regarding the concept of tuberculosis and its treatment (Kaulagekar-Nagarkar, Dhake, \& Jha, 2012). Non-adherence to treatment will slow the healing process of tuberculosis. The role of the family as drugtaking supervisor in children has an important role in accelerating the healing process and ensuring that the child completes his treatment regularly (Kementerian Kesehatan Republik Indonesia, 2014).Basedon the problems above, the researchers are interested in researching related the relationship between the role of the family as a drug taking supervisor with medication adherence in pulmonary tuberculosis children in the city of Jember.

\section{METHOD}

This research method is descriptive through the 2020 KMPK program internal evaluation indicators (JPP public health service and Rekomtek) and external evaluation indicators (by the Health Office on activities that have been carried out and obstacles faced and alternative solutions chosen).

The research design used is a cross sectional research type where the data collection method between the independent variable (independent) and the dependent variable (dependent) is carried out at the same time (Notoatmodjo, 2012). In this study, researchers analyzed the relationship between the role of the family as a drug-taking supervisor with medication adherence in children with pulmonary tuberculosis in the city of Jember. The population in this study were all families who became drug-taking supervisor for pulmonary tuberculosis children at the Kaliwates, Mangli, Jemberkidul and Patrang health centers. The sampling technique used total sampling with family criteria (father, mother, relatives or child caretakers) as a drug taking supervisor who treats child patients with tuberculosis aged 0-14 years and currently undergoing the treatment process and the families of patients who are willing or willing to become respondents. A total of 32 families acting as drug-taking supervisors participated in this study.

Data collection was carried out from March 2021 to June 2021 at the Kaliwates, Mangli, Jemberkidul and Patrang health centers. Before collecting data, the researcher applied for a research permit from the Kaliwates, Mangli, Jemberkidul and Patrang health centers. Then the researcher determines the research sample. The research instrument used was a questionnaire on the role of the family as a drug-taking supervisor and a questionnaire for adherence to medication for pulmonary tuberculosis children by modifying it and testing the Content Validity Index (CVI) to 3 lecturers at the Faculty of Nursing, University of Jember, focusing on Child Nursing. Therefore, the researchers had previously tested the validity and reliability of the two questionnaires.

Univariate analysis was conducted to describe the characteristics of the respondents which included the respondent's age, gender, occupation, education, relationship with the child, living at home with the child, the child's age, the history of the child's BCG vaccine and the nutritional status of the child. In addition, it is also to describe the role of the family as drug-taking supervisor and adherence to medication for pulmonary tuberculosis children. Meanwhile, Spearman's analysis (alpha $=0.05$ ) was conducted to determine the relationship between the role of the family as a drug-taking supervisor with medication adherence in children with pulmonary tuberculosis. The ethical feasibility test was carried out on the Research Ethics Committee of the Faculty of Dentistry, University of Jember with the number No.862/UN25.8/KEPK/DL/2020.

\section{RESULT}

The results of the content validity test have a value of +1 and the medication adherence questionnaire for pulmonary tuberculosis children. The content validity test has a value of +1 which means that the questionnaire is valid because $>0.8$. The results of the reliability test of the questionnaire on the role of the family as a drug-taking supervisor of 0.937 with an $r$ table value of 0.449 so that the value of $r$ Alpha $>r$ table, the questionnaire is declared reliable. While 
the results of the reliability test of the medication adherence questionnaire in children with pulmonary tuberculosis were 0.955 with an $r$ table value of 0.499 so that the $r$ Alpha value $>r$ table, the questionnaire was declared reliable.

\section{Univariate Analysis}

Table 1. Characteristics of Respondents Based on Respondent's Age, Gender, Education, Relationship with Children, Living at Home with Children, Child's Age, Child's BCG Vaccine History and Child's Nutritional Status ( $\mathrm{n}=32$ )

\begin{tabular}{|c|c|c|}
\hline Variable & Frequency & Percentage (\%) \\
\hline Respondent Age & \multirow{2}{*}{\multicolumn{2}{|c|}{$35.00(25-62)$}} \\
\hline Md (Min-Max) & & \\
\hline Child Age & \multirow{2}{*}{\multicolumn{2}{|c|}{$6.66 \pm 4.053$}} \\
\hline Mean \pm SD & & \\
\hline \multicolumn{3}{|l|}{ Gender } \\
\hline Man & 16 & 50 \\
\hline Woman & 16 & 50 \\
\hline \multicolumn{3}{|l|}{ Education } \\
\hline No school/elementary school & 6 & 18.8 \\
\hline Junior High School & 4 & 12.5 \\
\hline SHS/VHS/Equivalent & 20 & 62.5 \\
\hline Graduate & 2 & 6.2 \\
\hline \multicolumn{3}{|l|}{ Profession } \\
\hline Entrepreneur & 17 & 53.1 \\
\hline Housewife & 10 & 31.2 \\
\hline Labor & 5 & 15.6 \\
\hline \multicolumn{3}{|l|}{ Relationship with Children } \\
\hline Father & 16 & 46.9 \\
\hline Mother & 15 & 50 \\
\hline Grandmother & 1 & 3.1 \\
\hline \multicolumn{3}{|l|}{ Live Together } \\
\hline Yes & 32 & 100 \\
\hline No & 0 & \\
\hline \multicolumn{3}{|l|}{ Child BCG Vaccine History } \\
\hline Already & 29 & 90.6 \\
\hline Not yet & 3 & 9.4 \\
\hline \multicolumn{3}{|l|}{ Child Nutritional Status } \\
\hline Good & 14 & 43.8 \\
\hline Less & 18 & 56.2 \\
\hline
\end{tabular}

Based on table 1, the youngest respondent is 25 years old and the oldest is 62 years old, 16 respondents are male (50\%) and 16 female respondents (50\%), the most recent education of respondents is SHS/VHS/equivalent as many as 20 people. (62.5\%), the most occupations are entrepreneurs as many as 17 people $(53.1 \%)$, the relationship with the most children is father as many as 16 people (50\%), all live at home with children as many as 32 people (100\%), children's age the average was 6 years or preschool age, the history of the BCG vaccine was 29 people $(90.6 \%)$ and the nutritional status of the children was 18 people (56.2\%).

Table 2. The role of the family as a drug taking supervisor in the city of Jember in March 2020 ( $n=32)$

\begin{tabular}{lcc}
\hline Family Role Level & Frequency & Percentage (\%) \\
\hline Good & 25 & 78.1 \\
\hline Not good & 7 & 21.9 \\
\hline \multicolumn{1}{c}{ Total } & 32 & 100 \\
\hline
\end{tabular}
(78.1\%).

Based on table 2 the level of the role of the family as a drug taking supervisor is good as many as 25 people

Table 3. Drug adherence in children with pulmonary tuberculosis in the city of Jember in March 2020 ( $n=32)$ 


\begin{tabular}{|c|c|c|}
\hline Medication Compliance & Frequency & Percentage (\%) \\
\hline Low & 19 & 59.4 \\
\hline High & 13 & 40.6 \\
\hline Total & 32 & 100 \\
\hline
\end{tabular}

Based on table 3 the level of adherence to taking medication in children with pulmonary tuberculosis was low as many as 19 people (59.4\%).

\section{Bivariate Analysis}

Table 4. The relationship between the role of the family as a drug-taking supervisor with medication adherence in children with pulmonary tuberculosis in the city of Jember in March $2020(n=32)$.

\begin{tabular}{|c|c|c|c|c|c|}
\hline \multirow{2}{*}{$\begin{array}{l}\text { Family Role as Drug- } \\
\text { taking Supervisor }\end{array}$} & \multicolumn{2}{|c|}{ Medication Compliance } & \multirow{2}{*}{ Total } & \multirow{2}{*}{$p$ value } & \multirow{2}{*}{$r$} \\
\hline & High & Low & & & \\
\hline Good & 13 & 12 & 25 & 0.012 & 0.438 \\
\hline Not good & 0 & 7 & 7 & & \\
\hline Total & 13 & 19 & 32 & & \\
\hline
\end{tabular}

Based on table 4, the results of the Spearman analysis test the relationship between the role of the family as a drug-taking supervisor with medication adherence in pulmonary tuberculosis children in the Jember city area with $p$ value $=0.012$. Ha is accepted if the $p$ value $<$, it can be said that the $p$ value $<0.05$ is $0.012<0.05$. So that Ha is accepted, which means that there is a relationship between the role of the family as with medication adherence in pulmonary tuberculosis children at the Jember City Health Center. The correlation strength value is moderate with $\mathrm{r} 0.438$ which means that it has a positive or unidirectional relationship.

\section{DISCUSSION}

Based on the results of the study, it showed that there was a relationship between the role of the family as a drug taking supervisor with medication adherence in pulmonary tuberculosis children in the city of Jember. This is supported by the results of the study showing that 32 respondents indicated the role of the family as drug-taking supervisor in the good category, namely as many as 25 people (78.1\%). In line with Parulian's research (2014) that the role of the family shows a good category (93.3\%) (Parulian, 2014). The role of the family can make success in the treatment of children who are sick increase by improving the mental health of individuals or families directly. The role of the family is assumed to be something that is obtained to overcome the problems of other family members (Friedman, Bowden, \& Jones, 1998).

Based on the results of research that has been carried out on 32 respondents, it shows that adherence to medication in children shows a low level of adherence as many as 19 people. In line with Baharuddin's research (2019) that out of 42 children there were 17 children who were not compliant with tuberculosis treatment, 9 failed in treatment and 8 respondents recovered (Baharuddin, 2019).

Low adherence to medication in children with pulmonary tuberculosis is caused by factors from the children themselves, namely the lack of understanding of the child regarding the purpose of treatment so that education is needed for children in language that is easily understood by children, the tendency of children to get bored during treatment because of the length of time the treatment must take routinely for approximately 6 months and family support that involves emotional concerns, assistance and affirmation will make children not lonely in dealing with situations and family support can empower children with pulmonary tuberculosis by supporting them continuously, such as accompanying children to take medicine and being sensitive to children when drug side effects occur (Marlinae, et al., 2019).

The success of treatment is strongly influenced by the family because the behavior of the family is not good for the child, the healing process will be difficult to achieve and maybe the child's condition will get worse. Therefore, it is expected that the role of the family in care in achieving treatment success (Sidabutar, 2018). Supporting from families helps tuberculosis sufferers in the healing process, where the family is tasked with providing encouragement and support so that tuberculosis patients recover quickly, such as reminding patients to take medicine regularly, taking patients to take medicine at the Puskesmas if the patient cannot go alone and always by the side of the patient if patients need (Yoisangadji, Maramis, \& Rumayar, 2016). 


\section{CONCLUSION}

There was a relationship between the role of the family as a drug-taking supervisor with medication adherence in pulmonary tuberculosis children in the Jember city area with a $p$ value $<0.05$, i.e. $0.012<0.05$. The value of the strength of the relationship is moderate with an $r$ value of 0.438 which means it has a un-directional relationship with the meaning that the better the role of the family as drug-taking supervisor, the higher the level of adherence to taking medication in children with pulmonary tuberculosis. It is necessary to increase the role of the family as drug-taking supervisor in an effort to improve drug adherence in children with pulmonary tuberculosis. Families must always accompany the child until the treatment process is complete so that there will be no drug withdrawal or drug resistance. In addition, health workers also need to educate families regarding the process that will be passed while becoming a drug-taking supervisor and what to do if the effects of treatment occur.

\section{ACKNOWLEDGEMENT}

The author would like to thank the alma mater of the Faculty of Nursing, University of Jember as a place of study and research guidance, especially the PERCASA research group. Thanks also to Kaliwates, Mangli, Jember Kidul and Patrang Health Centers who have given permission to conduct research and participate in this research.

\section{REFERENCES}

Baharuddin. (2019). Faktor yang Mempengaruhi Tingkat Kegagalan Pengobatan Pasien Tuberkulosis Paru pada Anak di Puskesmas Kota Makasar. Jurnal Keperawatan Poltekkes Makasar , 680-685.

Departemen Kesehatan Republik Indonesia. (2006). Pedoman Penyakit Tuberkulosis dan Penanggulangannya. Retrieved from Departemen Kesehatan Republik Indonesia.

Departemen Kesehatan Republik Indonesia. (2018). Profil Kesehatan Jawa Timur 2017. Retrieved July 26, 2019, from Departemen Kesehatan Jawa

Timur: http://www.depkes.go.id/resources/download/profil/PROFIL_KES_PROVINSI_2017/15_Jatim_2017.pdf

Friedman, M. M., Bowden, V., \& Jones, E. (1998). Family Nursing: Research Theory and Practice (5th Edition ed.). New Jersey: Prentice Hall.

Kaulagekar-Nagarkar, A., Dhake, D., \& Jha, P. (2012). Perspective of Tuberculosis Patients on Family Support and Care in Rural Maharashtra. Indian Journal of Tuberculosis , 224-230.

Kementerian Kesehatan Republik Indonesia. (2019). Data dan Informasi Profil Kesehatan Indonesia. Retrieved July 26, 2019, from Kemenkes Rl: http://www.depkes.go.id/resources/download/pusdatin/profil-kesehatanindonesia/Data-dan-Informasi_ProfilKesehatan-Indonesia2018.pdf

Kementerian Kesehatan Republik Indonesia. (2013). Pedoman Nasional Penanggulangan Tuberkulosis. Retrieved from Kementerian Kesehatan Republik Indonesia.

Kementerian Kesehatan Republik Indonesia. (2014). Petunjuk Teknis dan Manajemen Tatalaksana TB Anak. Retrieved from Kementerian Kesehatan Republik Indonesia.

Marlinae, Lenie, Arifin, Syamsul, Noor, Hazairin, I., et al. (2019). Desain Kemandirian Perilaku Kepatuhan Minum Obat pada Penderita TB Paru Anak Berbasis Android. SEMNASKes-2019, 141-145.

Notoatmodjo, S. (2012). Metode Penelitian Kesehatan. Jakarta: Rineka Cipta.

Parulian, H. (2014). Hubungan Peran Keluarga dengan Tingkat Keberhasilan Pengobatan Pasien Tuberkulosis Paru pada Anak Usia Sekolah di Balai Pengobatan Paru-paru (BP.4) Medan. Jurnal Keperawatan Flora , 1-12.

Sidabutar, R. R. (2018). Hubungan Peran Keluarga dengan Tingkat Keberhasilan Pengobatan TBC Paru Anak Usia Sekolah di Balai Pengobatan Paru-paru (BP.4). Jurnal Keluarga Sehat Sejahtera, 60-72.

Widiyanto, A. (2016). Hubungan Kepatuhan Minum Obat dengan Kesembuhan Pasien Tuberkulosis Paru BTA Positif di Puskesmas Delanggu Kabupaten Klaten. Jurnal Terpadu IImu Kesehatan , 6(1), 7-12.

World Health Organization. (2013). Retrieved July 02, 2019, from Tuberculosis Profile: www.who.int/tb/data

World Health Organization. (2018). Roadmap Toward Ending TB in Children and Adolescent. Retrieved July 26, 2019, from World Health Organization: https://www.who.int/tb/areas-ofwork/children/en/

Yoisangadji, A. S., Maramis, F. R., \& Rumayar, A. A. (2016). Hubungan Antara Pengawas Menelan Obat (PMO) dan Peran Keluarga dengan Kepatuhan Minum Obat pada Pasien Tuberkulosis di Wilayah Kerja Puskesmas Sario Kota Manado. Jurnal IImiah Farmasi , 138-143. 